\title{
Multidrug and Toxin Extrusion Protein 2
}

National Cancer Institute

\section{Source}

National Cancer Institute. Multidrug and Toxin Extrusion Protein 2. NCI Thesaurus. Code C113569.

Multidrug and toxin extrusion protein 2 (602 aa, $\sim 65 \mathrm{kDa}$ ) is encoded by the human SLC47A2 gene. This protein is involved in both excretion of toxic electrolytes and secretion of cationic drugs. 